\title{
Yüksek Sıcaklık Uygulamalarında Kullanılmak Üzere Kimyasal İşlemden Geçirilmiş Hibrit Jüt - Keten Doğal Kompozitlerin Geliştirilmesi
}

\author{
Mehmet Fatih ÖKTEM*, Büşra ALTINTOP \\ Ankara Yıldırım Beyazıt Üniversitesi, Mühendislik ve Doğa Bilimleri Fakültesi, Metalürji-Malzeme Mühendisliği \\ Bölümü, Ankara, Türkiye
}

\begin{abstract}
Composite materials utilizing natural fibers are becoming more popular and have a broad range of usage in the industry. Natural fibers come from nature and they have many advantages which are low cost, easily available and environmentally friendly. Some natural fibers are obtained from plants while others could be obtained from trees. Commonly used natural fibers are jute, flax, sisal, bamboo and ramie. In order to produce composite materials from natural fibers, both thermoset and thermoplastic resins can be used. In this experimental study, epoxy resin was combined with jute and flax woven fibers to obtain hybrid composites. Firstly, fibers were treated with a solution containing $5 \%$ alkaline to improve the mechanical properties of the fibers. Two different chemicals were used to improve the fire resistance of the fibers namely ammonium sulfate and diammonium phosphate. Two different solutions were prepared for this purpose; a solution containing $20 \%$ of ammonium sulfate was prepared for the treatment of jute fiber and another solution containing $10 \%$ of diammonium phosphate was prepared for the treatment of flax fiber. The epoxy was applied to both samples by hand layup method and the curing was carried out by using the hot press. The hardness, thickness and mass of the produced samples were measured and a fire experiment was carried out. Several parameters such as flammability, heat distribution and temperature of the sample surfaces were investigated. Low flammability, low heat distribution and low temperature properties were observed on the surfaces of the samples which were chemically treated by using ammonium sulfate and diammonium phosphate.
\end{abstract}

Keywords: Natural composites, jute, flax, fire retardants.

\section{Development of Chemically Treated Hybrid Jute - Flax Natural Composites for Elevated Temperature Applications}

\begin{abstract}
$\ddot{O} \mathbf{z}$
Doğal fiberleri içeren kompozit malzemeler günümüzde daha popüler hale gelmekte, bununla birlikte bu malzemeler endüstride geniş uygulama alanları bulmaktadır. Doğal fiberlerin biyo uyumluluk, düşük maliyet, kolay bulunabilirlik ve çevreye duyarlılık gibi avantajları bulunmaktadır. Bazı doğal fiberler bitkilerden elde edilirken, bazıları da ağaçlardan elde edilebilmektedir. En çok kullanılan doğal fiberler jüt, keten, sisal, bambu ve ramidir. Doğal fiberlerden kompozit malzeme üretmek için hem termoset hem de termoplastik reçineler kullanılabilmektedir. Bu deneysel çalışmada, epoksi reçine kullanılarak jüt ve keten fiber kumaşlar kullanılarak hibrit bir kompozit malzeme üretilmiştir. Çalışmanın ilk etabında, fiberler \% 5 alkali içeren bir çözelti içerisinde fiberlerin mekanik özelliklerini artırmak amacıyla kimyasal işleme tabi tutulmuşlardır. Fiberlerin yangın dayanımını artırmak için iki farklı kimyasal kullanılmıştı; amonyum sülfat ve diamonyum fosfat. Bu iki kimyasal madde kullanılarak ilki \% 20 amonyum sülfat içeren jüt fiberi kimyasal işleme tabi tutmak için bir çözelti, ikincisinde ise \% 10 diamonyum fosfat içeren keten fiberi kimyasal işleme tabi tutmak için bir başka çözelti hazırlanmıştır. Epoksi reçine elle yatırma yöntemiyle her iki numuneye uygulanmış, sıcak pres kullanılarak da kürleşme işlemi gerçekleştirilmiştir. Üretilen numunelerin sertlik, kalınlık ve kütleleri ölçülerek ardından yangın deneyi gerçekleştirilmiştir. Alev alabilirlik, 1sı dağılımı ve numune yüzeylerinin ulaştığı sıcaklık değerleri gibi çeşitli parametreler incelenmiştir. Düşük alevlenebilirlik, düşük 1sı dağılımı ve düşük sıcaklık gibi değerler amonyum sülfat ve diamonyum fosfat ile kimyasal işleme tabi tutulmuş numunelerin yüzeylerinde gözlemlenmiştir.
\end{abstract}

Anahtar kelimeler: Doğal kompozitler, jüt, keten, yangın geciktiriciler.

\footnotetext{
*Sorumlu yazar: mfoktem@ybu.edu.tr

Geliş Tarihi: 30.07 .2018 , Kabul Tarihi:30.10.2018
} 


\section{Introduction}

At least two different materials or phases that are combined in macro or micro dimensions to form a new material are called composite material. Composite materials are formed by the matrix and the reinforcement materials. Composite materials have many advantages such as high strength to low density ratio, corrosion resistance, thermal resistance and etc. The application areas of composite materials are also very broad from military to civil areas.

There are three types of composite materials based on the matrix material namely polymer matrix composites, metal matrix composites and ceramic matrix composites. One of the most important advantages of using polymers as the matrix material is the ease of processing, manufacturability, and cost reduction. In some applications, the properties of polymers are modified by using fillers and fibers to suit the high strength and high modulus requirements [1].

\subsection{Natural fibers}

Natural fibers are obtained from animals and vegetables. Although the major chemical composition of these fibers is cellulose, they may also contain other components, such as lignin, hemicellulose, and inorganic salts often identified as ash [2]. Natural fiber composites are generally used where a moderate strength is required i.e. housing, roofing and in other secondary structure applications [3]. Natural fibers have many advantages compared to synthetic fibers. They can be listed as low cost, renewability and ease of availability. However, they have high water absorption, low fire resistance and are less durable.

Natural fibers can be grouped into three: seed hair, bast and leaf fibers, depending upon the source. Some examples are cotton (seed hairs), ramie, jute and flax (bast fibers), and sisal and ablaca (leaf fibers). Of these fibers, jute, ramie, flax and sisal are the most commonly used fibers for producing polymer matrix composites. Mechanical properties of five natural fibers are given in Table 1.

Table 1. Mechanical properties of some natural fibers [1]

\begin{tabular}{|c|c|c|c|c|}
\hline Type of fiber & $\begin{array}{c}\text { Specific } \\
\text { gravity }\end{array}$ & $\begin{array}{c}\text { Tensile } \\
\text { strength (MPa) }\end{array}$ & $\begin{array}{c}\text { Young's Modulus } \\
\text { (Longitudinal direction) (GPa) }\end{array}$ & $\begin{array}{c}\text { Specific } \\
\text { modulus }\end{array}$ \\
\hline Jute & 1.3 & 393 & 55 & 38 \\
\hline Sisal & 1.3 & 510 & 28 & 22 \\
\hline Flax & 1.5 & 344 & 27 & 50 \\
\hline Sun hemp & 1.07 & 389 & 35 & 32 \\
\hline Pineapple & 1.56 & 170 & 62 & 40 \\
\hline
\end{tabular}

The properties of natural fibers depend on chemical composition and micro structure. If the concentration of cellulose in natural fibers increases, so as the mechanical properties. The fire resistance of the natural fibers is not promising; one of the methods to improve the fire resistance of these fibers is to treat these fibers with fire retardant chemical compounds [4].

\subsubsection{Jute fibers}

Jute fiber is one of the most commonly used reinforcement material for natural fiber composites. Jute fibers are primarily composed of the plant substances e.g. cellulose, lignin, and pectin. This material, which can be used in a wide variety of areas, has been preferred by many companies with its natural structure and harmlessness to health.

Jute is mostly extracted from the bark of the white jute plant (Corchorus capsularis) and to a lesser extent from tossa jute (C.olitorius). It is a natural fiber with golden and silky shine and hence called the golden fiber as well. The plant stems are about 2.5 to 3.5 meters tall and as thick as a finger. 
Most of the jute is produced in India and Pakistan in the Southeast Asia. The names of other countries that follow these countries are the states of Texas and South Carolina in the United States of America (U.S.A.). Jute plant is not grown in Turkey but there are regions which are suitable for jute agriculture such as Antalya, Adana and Hatay.

Jute fiber is $100 \%$ bio-degradable and recyclable and thus environmentally friendly. A hectare of jute plant consumes about 15 tons of carbon dioxide and releases 11 tons of oxygen. There is an advantage of the jute plant regarding the fire safety; it does not generate toxic gases when burnt.

\subsubsection{Flax fibers}

Flax is the one of the strongest natural fibers among the natural cellulosic fibers. The main constituents of a flax fiber are cellulose, hemicellulose, wax, lignin and pectin, in varying quantities. Flax fibre is rich in cellulose which accounts for about $70 \%$ of the total chemical composition. This enables flax to be widely considered as reinforcement in producing composites [5]. Flax fiber composites are being used in the forms of tubes, sandwich panels, fixtures, furniture and car body parts. There is an increasing demand from automotive companies for materials both with sound reduction capability and low weight for fuel efficiency [6].

Flax is a plant which belongs to linaceae family and is one of the widely utilized natural fiber. These fibers are produced in many countries like Egypt, Brazil, Ukraine, China, Australia, Belgium, France and Russia. Flax plant can also be grown in central and northern Europe and Turkey is a good place to grow this plant. The process of obtaining the dried plant fiber takes place in three stages, namely rebuttal, hiding and carding. Flax woven fabric which is produced from the flax fiber is a good candidate to produce composite materials.

\subsection{Chemical treatments}

Jute and flax fibers have some drawbacks such as high water absorption and low fire resistance. Some processes need to be applied to improve these properties. There are several chemical treatments applied to natural fibers that are alkaline treatment, acetylation, graft copolymerization and silane treatment. In this research, alkaline treatment was applied to reduce water absorption of the woven fibers and fire retardants were applied to reduce flammability.

\subsubsection{Alkaline treatment}

Alkaline treatment removes fiber constituents including hemicellulose, lignin, pectin, fat and wax which exposes cellulose and increases surface roughness/area ratio to improve interfacial bonding [7]. The treatment of natural fibers by sodium hydroxide $(\mathrm{NaOH})$ is widely being used to modify the cellulosic molecular structure [8].

The efficiency of the alkaline treatment depends on the concentration of the alkaline solution, process duration and temperature. Mishra et al. found that the treatment of sisal fibers with $5 \% \mathrm{NaOH}$ solution gave higher tensile strength to the obtained composite product compared to treatment with 10 $\% \mathrm{NaOH}$ solution [9]. At higher concentrations of the alkaline process, the removal of lignin in excess amount results in decreasing the strength of the material.

\subsubsection{Fire retardants}

Natural fibers have high flammability; treatment of fibers with the help of fire retardants would expand their uses in elevated temperature applications [4]. The most commonly used fire retardants are based on halogens, phosphorus, boron, ammonium compounds, graphite, and alkaline earth metallic compounds [10]. Ideal fire retardants must be environmentally friendly, have low smoke content, low toxic potential and low corrosivity.

Jute has a high proneness to burning like all other natural fibers, though Limiting Oxygen Index (LOI) of untreated jute (20.5) is higher than that of untreated flax (17.4) [11]. When fire retardant is added to jute and flax, LOI increases and reduces flammability. 
Fire retardants used for jute are urea, sulfamic acid and ammonium sulfate. Fire retardants used for flax are diammonium phosphate, ammonium polyphosphate, mono ammonium phosphate and vinly phosphonic acid.

\subsection{Hybrid composites}

Hybrid composites are materials, made by combining two or more different types of fibers (woven/nonwoven) bonded by the same matrix. The possible combinations of hybrid composites are artificialartificial, natural-artificial and natural-natural fibers [12]. The reason why a hybrid structure is preferred in this study is flax has a soft and a brighter appearance and jute has better mechanical strength; a combination of these two different types of fibers, flax woven fabric on the two outer sides of the structure and jute woven fabric in the inner side of the structure exploit the advantages of these two.

Several polymers could be used as the matrix material to produce a natural fiber composite material. Polyester, epoxy and vinyl ester are just a few to mention. Epoxy was preferred in this study because of its better mechanical strength and ease of use.

\section{Experimental Procedure}

\subsection{Sample preparation}

In this study, two different natural woven fibers were used. Natural fibers have many advantages, but they have some disadvantages that need to be improved. These disadvantages are low fire resistance, low mechanical properties and high water absorption. The aim of this research is to improve these properties and have an aesthetic design by using the flax woven fabric at the outer surfaces.

Two samples were produced for this purpose. The first sample was used as reference and no fire retardant chemical was applied; only alkaline treatment was carried out to improve the mechanical strength and the bonding capability of the fibers. Alkaline and fire retardants were applied to the second sample.

Jute and flax fiber woven fabrics were cut to $25 \times 25 \mathrm{~cm}$ dimensions, 12 pieces in total. The masses of the fibers were measured by precise scale as shown in Figure 1.

The jute and flax fiber woven fabrics were kept in deionized water for 30 minutes for cleaning. Then they were put to drying in the dark room for 24 hours. In this study 5:1 ratio was used for sodium hydroxide-deionized water solution. $120 \mathrm{~g}$ of $\mathrm{NaOH}$ was mixed with 2.4 liters deionized water and the fibers were waited to stand in the solution for 4 hours and then fabrics were kept in deionized water. After the rinsing process the fabrics dried at room temperature for 24 hours.

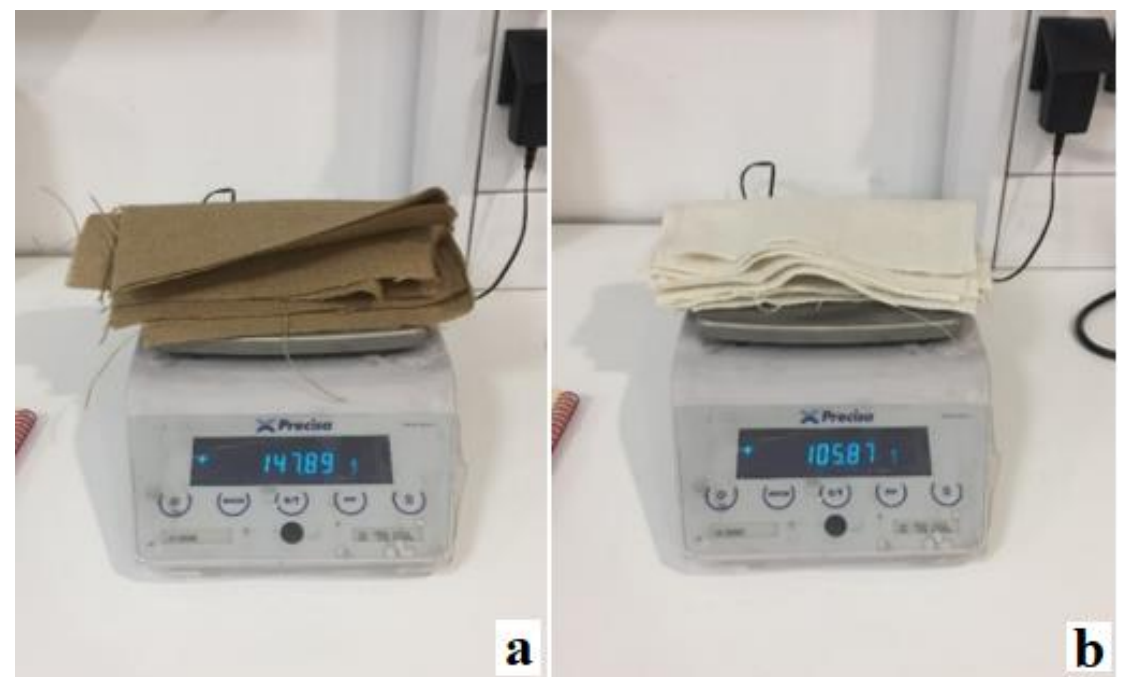

Figure 1. Mass of jute fabrics (a), Mass of flax fabrics (b)

After the alkaline treatment of the fabrics, the masses and thicknesses of the fabrics were measured again. The initial dimensions of the fabrics were $25 \times 25 \mathrm{~cm}$, small pieces were obtained by cutting the 
$25 \times 25 \mathrm{~cm}$ fabrics into $10 \times 10 \mathrm{~cm}$ dimensions, so a total of 48 pieces of plies were obtained ( 24 plies of $10 \times 10 \mathrm{~cm}$ flax fabrics and 24 plies of $10 \times 10 \mathrm{~cm}$ jute fabrics were obtained).

\subsubsection{First sample preparation}

The first sample that is composed of 4 plies from jute and 4 plies from flax was used as reference sample to compare with the other sample which is chemically treated to improve the fire resistance. The epoxy resin was obtained from Duratek ${ }^{\circledR}$ Company and $80 \mathrm{~g}$ of epoxy resin (A) and $20 \mathrm{~g}$ hardener (B) were used for 8 plies hybrid structure. The resin mixture was prepared just before the lamination process of the fabrics because of the limited pot life of the resin and hardener mixture. Figure 2 shows the epoxy and hardener cans and the mixture right before the application.
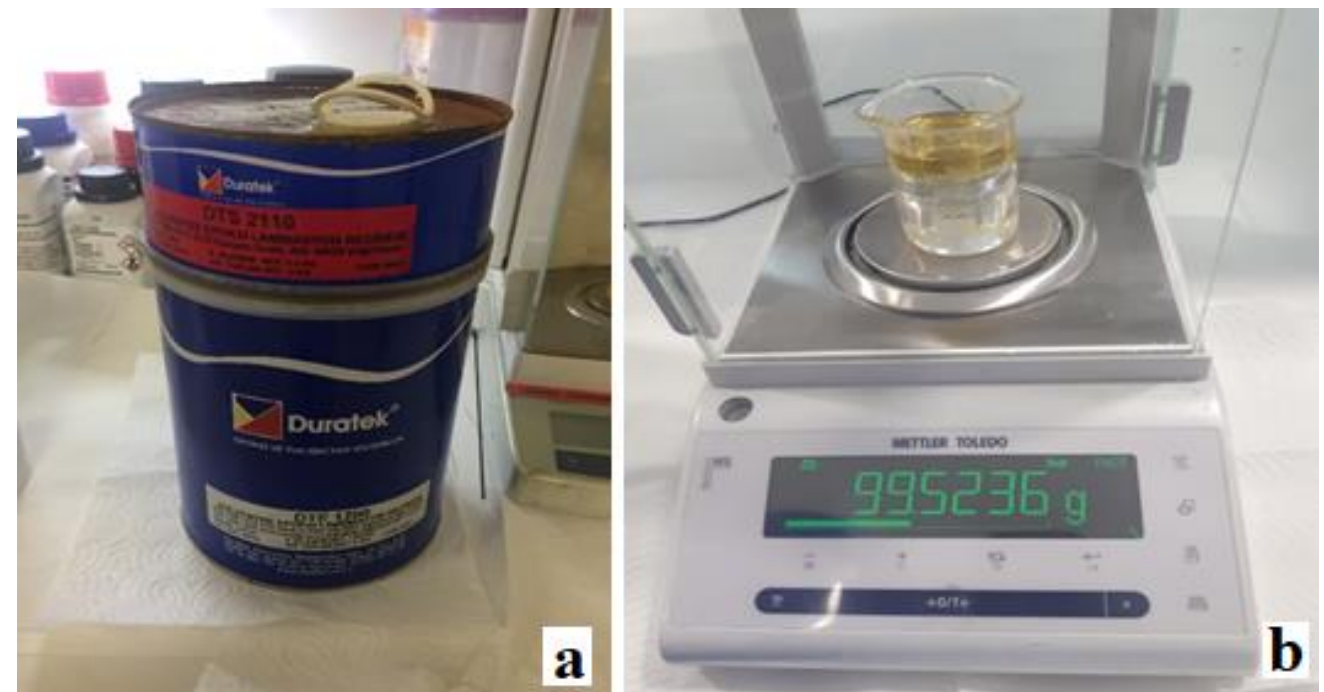

Figure 2. Epoxy and hardener (a), Epoxy and hardener mixture (b)

In order to produce a single laminated hybrid composite structure, two flax fabrics were laminated on the lower side and two flax fabrics were laminated on the upper side of the structure. In the middle of the structure, four jute plies were laminated. In order to produce a hybrid laminated structure, a total of eight plies were used. The resin mixture was applied by hand layup method by using a brush. $100 \mathrm{~g}$ of resin mixture was applied with brush to eight plies. After the lamination process, the hybrid structure was put to hot press for curing process. The curing process was done at $100{ }^{\circ} \mathrm{C}$ for 4 hours and 0.5 tons of force was applied. Figure 3 shows the hand layup process and hot press used in the curing process.

\subsubsection{Second sample preparation}

The second sample was rinsed with deionized water, and then alkaline treatment was carried out as was in the first sample but both the jute and flax fabrics were treated with fire retardants which is a different process from the first sample. Separate treatment was applied for jute and flax fabrics. Ammonium sulfate was used for the treatment of jute fabrics and diammonium phosphate was used for the treatment of flax fabrics.

A solution containing $20 \%$ of ammonium sulfate was used for the treatment of jute fabrics. 480 $\mathrm{g}$ of ammonium sulfate was mixed with 2.4 liters deionized water and the fibers were waited to stand in the mixture for 15 minutes. Then they were put to drying at room temperature for 24 hours.

A solution containing $10 \%$ of diammonium phosphate was used for the treatment of flax fabrics. $240 \mathrm{~g}$ of diammonium phosphate was mixed with 2.4 liters deionized water and the fibers were waited to stand in the mixture for 10 minutes. Then they were put to drying at room temperature for 24 hours. Figures 4 and 5 show the chemicals and the treatment of the fabrics.

The second sample is also composed of 4 plies from jute and 4 plies from flax fabrics. The same amount of epoxy resin and hardener (80 g epoxy and $20 \mathrm{~g}$ hardener) were used for 8 plies hybrid 
structure. The resin mixture was prepared just before the lamination process of the fabrics because of the limited pot life of the resin and the hardener mixture.

The same lamination sequence was used as was the case for the first sample. The resin mixture was applied by hand layup method by using a brush. $100 \mathrm{~g}$ of resin mixture was applied with brush to eight plies. After the lamination process, the hybrid structure was put to hot press for curing process. The curing process was done at $100{ }^{\circ} \mathrm{C}$ for 4 hours and 0.5 tons of force was applied.

The produced samples after both processes are shown in Figure 6. Then the hardness values of these samples were measured with a durometer and the thickness values were measured by the help of a caliper. The measurements were done from different points of the samples and the arithmetic averages of these values were used.

The fire experiments were conducted after the measurement of thickness and hardness. Heat was applied from the center of the sample with the flame gun of about $40 \mathrm{~cm}$ away from the sample. The temperature of the sample surfaces was measured when applying heat. The experimental setup is shown in Figure 7. The equipments used in fire experiment are flame gun, metallic stand and thermometer.
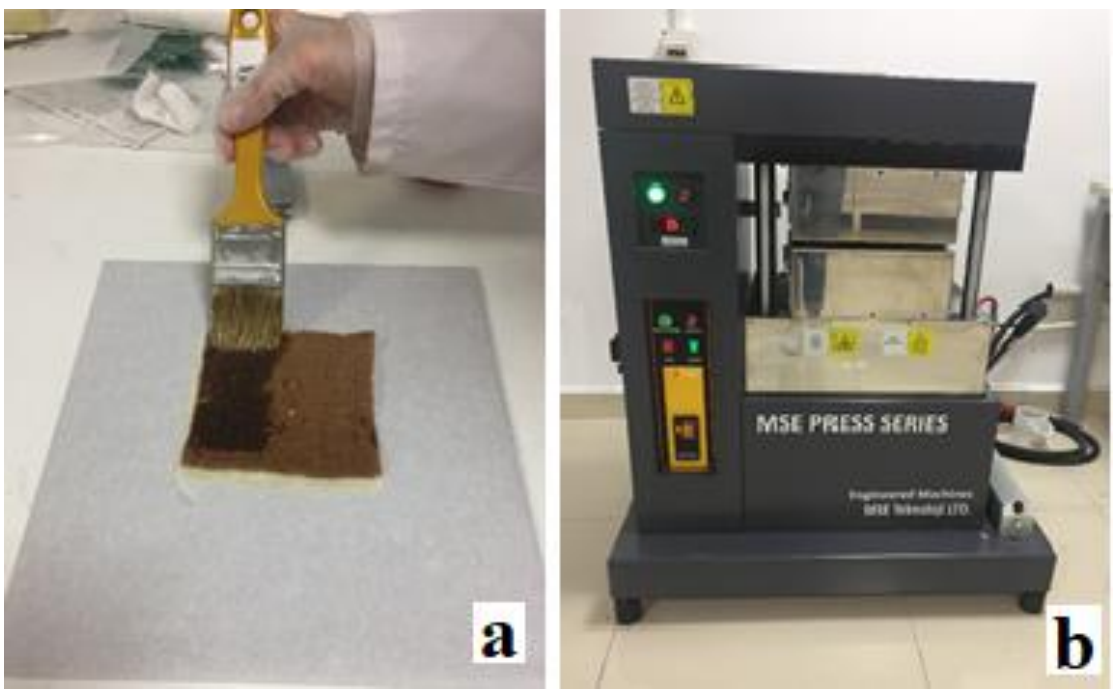

Figure 3. Hand layup method (a), Hot press (b)
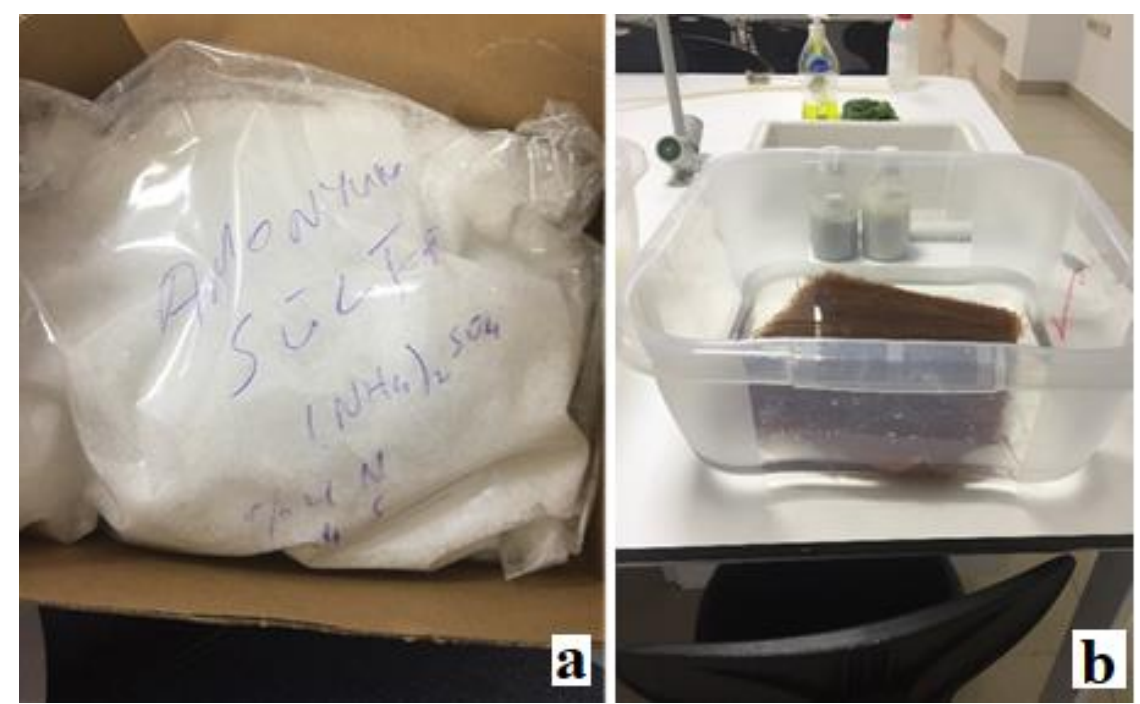

Figure 4. Ammonium sulfate (a), Treatment of jute fabrics (b) 


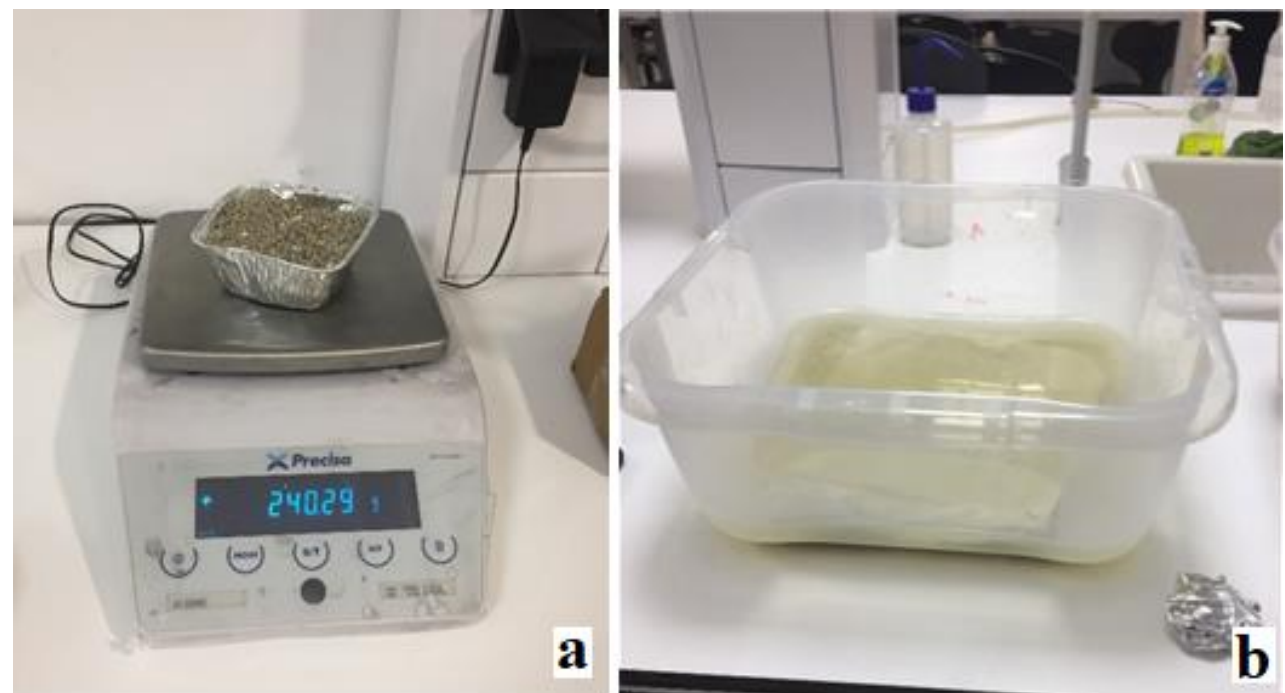

Figure 5. Diammonium phosphate (a), Treatment of jute fabrics (b)

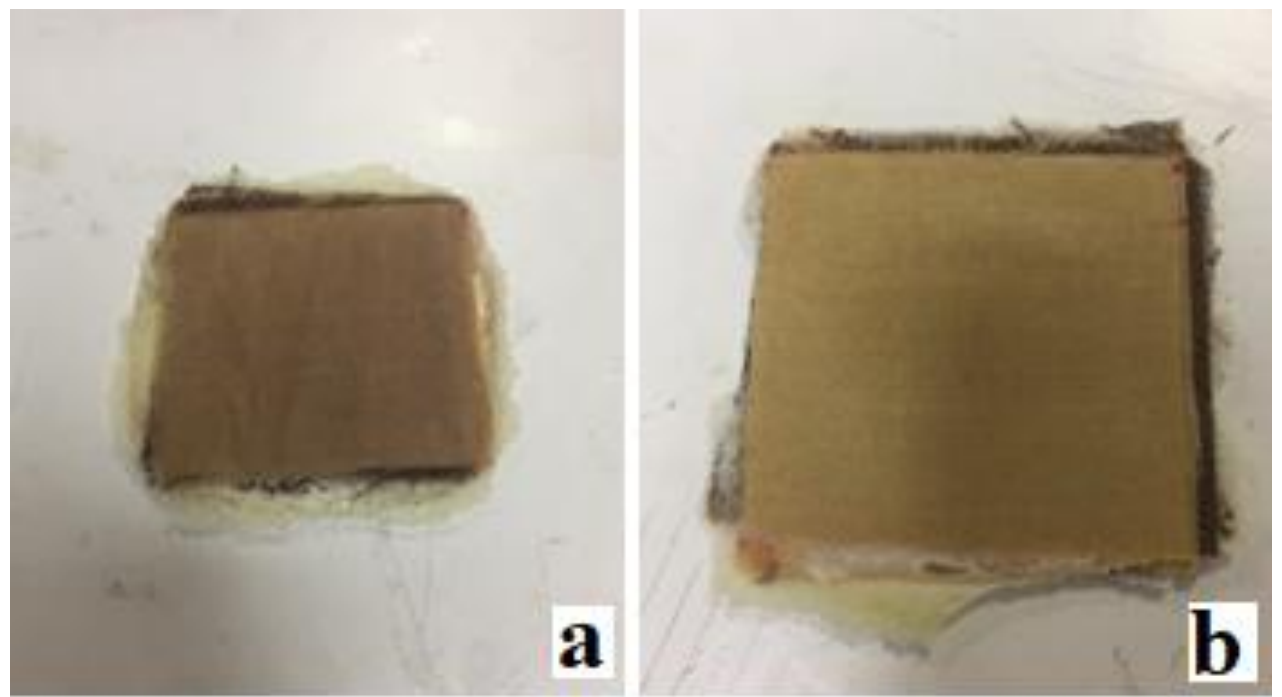

Figure 6. Sample 1 (without fire retardants) (a), Sample 2 (with fire retardants) (b)

\section{Results and Discussion}

The aim of this research is to improve the fire resistance and mechanical properties of hybrid jute/flax composite structures and have an aesthetic design. In this study, various chemical treatment methods were used to improve these properties. First, the fibers were treated with alkaline to improve their mechanical properties. In order to improve the fire resistance and to obtain a structure that can withstand elevated temperatures, two different chemicals were used i.e. ammonium sulfate and diammonium phosphate. One sample (sample 1) was used as a reference sample for comparison that was only treated with alkaline and no fire retardant was used. After producing the samples, hardness was measured with durometer (Shore D). It was observed that the mechanical properties were improved with the alkaline treatment and fire resistance of the sample (sample 2) that was treated with ammonium sulfate and diammonium phosphate has improved considerably. For the manufacturing process, hot press was used, this method is known to improve the mechanical strength of the laminated structure and decrease the void content.

Thickness and mass values of jute and flax fiber fabrics before and after alkaline treatment are given in the Table 2. The hardness and thickness of the cured laminated structures of the two samples are given in Table 3. Based on the results given in Tables 2 and 3, the mass of jute fabrics has decreased after alkaline treatment while the mass of the flax fabrics has increased after the same treatment. The 
thicknesses of the plies have increased considerably after the alkaline treatment for both fiber types. The hardness value of sample 1 is slightly lower than that of sample 2. Both samples were treated with alkaline but the sample 2 was treated with fire retardants after the alkaline treatment. This shows that the use of fire retardants has increased the hardness of the sample 2. The use of fire retardants has decreased the thickness of the cured laminated structure at the same time.

During the fire experiments three parameters were investigated. These parameters are: flammability, heat distribution and surface temperature of the samples. First, flammability was investigated between the two samples. Higher flame was observed on the sample without fire retardant (sample 1) but lower flame was observed on the fire retardants applied sample (sample 2). Then, heat distribution was investigated between the two samples. Less heat distribution was observed in the sample 2 while higher heat distribution was observed in the sample 1. Finally, surface temperatures were measured. The measured surface temperatures are $270{ }^{\circ} \mathrm{C}$ and $90{ }^{\circ} \mathrm{C}$ for sample 1 and sample 2 respectively. Heat distributions of both sample surfaces are shown in Figure 8. An aesthetic design has been obtained by using flax fabrics on the two outer sides of the composite while jute fabrics were used in the inner side of the structure.

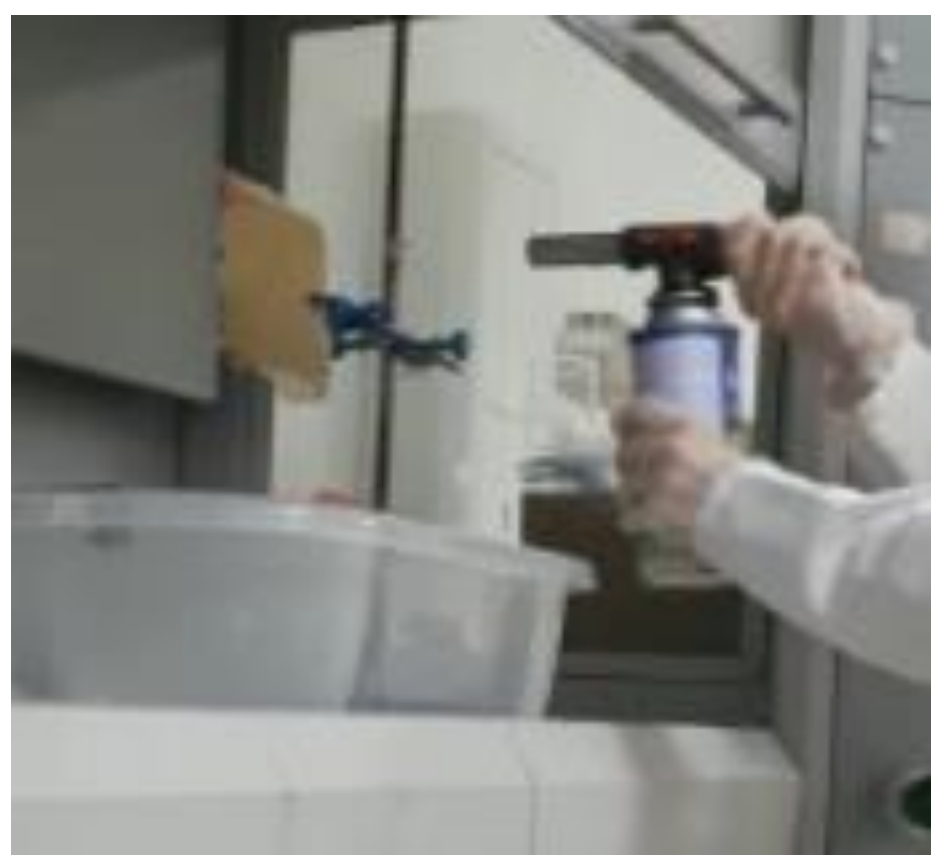

Figure 7. Fire experimentation setup inside the fume hood

Table 2. Mass and thickness results of jute and flax fabrics

\begin{tabular}{|c|c|c|}
\hline & Mass $(\mathbf{g})$ & $\begin{array}{c}\text { Arithmetic average thickness of a ply } \\
(\mathbf{m m})\end{array}$ \\
\hline $\begin{array}{c}\text { Jute fabrics before alkaline } \\
\text { treatment }\end{array}$ & 147.90 & 0.98 \\
\hline $\begin{array}{c}\text { Jute fabrics after alkaline } \\
\text { treatment }\end{array}$ & 137.71 & 1.33 \\
\hline $\begin{array}{c}\text { Flax fabrics before alkaline } \\
\text { treatment }\end{array}$ & 105.87 & 0.59 \\
\hline $\begin{array}{c}\text { Flax fabrics after alkaline } \\
\text { treatment }\end{array}$ & 108.31 & 0.75 \\
\hline
\end{tabular}


Table 3. Hardness and thickness results

\begin{tabular}{|c|c|c|}
\hline & Hardness (Shore D ) & Thickness of cured laminated structure (mm) \\
\hline Sample 1 & 88.3 & 5.6 \\
\hline Sample 2 & 91.1 & 4.7 \\
\hline
\end{tabular}
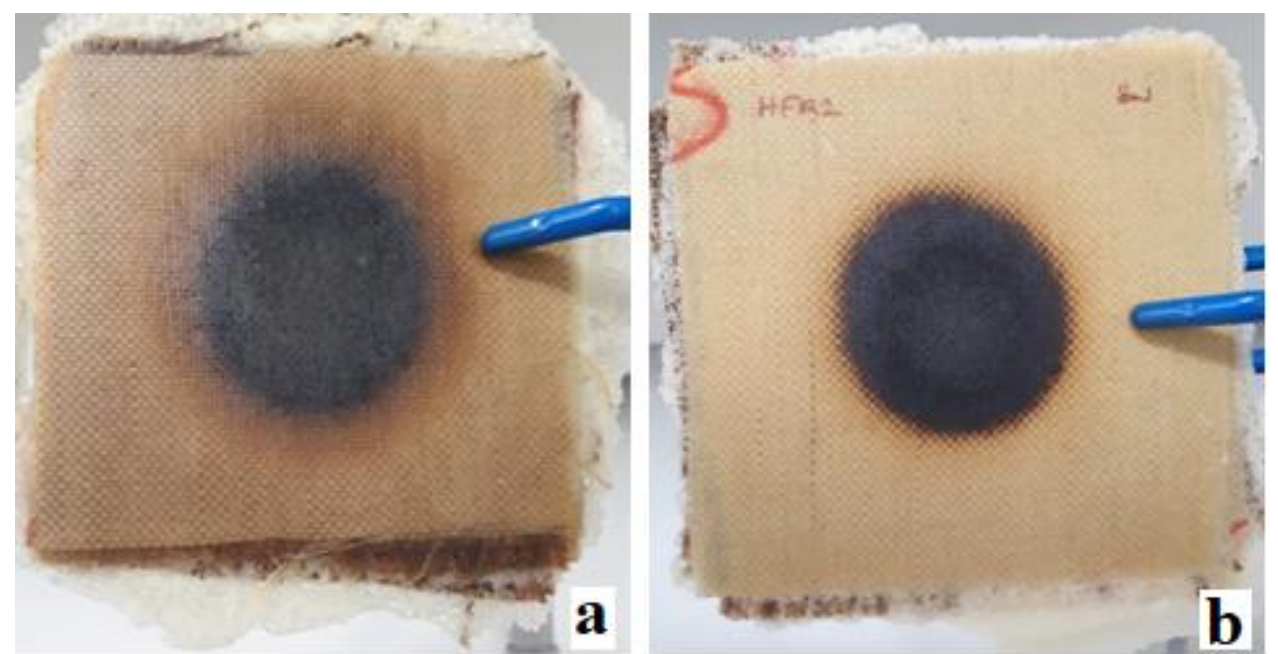

Figure 8. Sample 1 (without fire retardant) (a), Sample 2 (with fire retardants) (b)

\section{Acknowledgement}

The authors are grateful to Duratek ${ }^{\circledR}$ Company for providing the epoxy resin.

\section{References}

[1] Saheb N., Jog J. 1999. Natural Fiber Polymer Composites: A Review, Adv. in Polymer Technology, 2329 (July): 351-363.

[2] Salmeia K.A., Jovic M., Ragaisiene A., Rukuiziene Z., Milasius R., Mikucioniene D., Gaan S. 2016. Flammability of Cellulose - Based Fibers and the Effect of Structure of Phosphorus Compounds on Their Flame Retardancy, Polymers, 8 (293): doi:10.3390/polym8080293.

[3] Alves C., Ferrao P.M.C., Silva A.J., Reis L.G., Freitas M., Rodrigues L.B., Alves D.E. 2010. Ecodesign of automotive components making use of natural jute fiber composites, Journal of Cleaner Production, 18: 313-327.

[4] Statheropoulos M., Kyriakou S.A. 2000. Quantitative thermogravimetric-mass spectrometric analysis for monitoring the effects of fire retardants on cellulose pyrolysis, Anal. Chim. Acta, 409: 203-214.

[5] Yan L., Chouw N., Jayaraman K. 2014. Flax fibre and its composites - A review, Composites Part B, 56: 296-317.

[6] Yukseloglu S., Canoglu S. 2017. Leatherwork natural fibre composites: a review on flax fibers, Annals of the Oradea University Fascicle of Textiles, Leatherwork, pp. 137-142.

[7] Pickering K.L., Efendy M.G.A., Le T.M. 2016. A review of recent developments in natural fibre composites and their mechanical performance, Composites Part A, Appl. Sci. Manuf., 83: 98-112.

[8] Kabir M.M., Wang H., Lau K., Cardona F. 2012. Chemical treatments on plant-based natural fibre reinforced polymer composites: An overview, Composites Part B, 43 (7): 2883-2892. 
[9] Mishra S., Mohanty A., Drzal L.T., Misra M., Parija S., Nayak SK. 2003. Studies on Mechanical Performance of Biofibre/Glass Reinforced Polyester Hybrid Composites, Journal of Composite Science and Technology, 63 (10): 1377-1385.

[10] Molaba T.P., Chapple S., John M.J. 2019. Flame retardant treated flax fibre reinforced phenolic composites: Ageing and thermal characteristics, Journal of Fire and Materials, 42 (1): 50-58.

[11] Samanta A.K., Roy R.B., Chowdhury R. 2015. Fire-retardant Chemical Finishing of Jute Fabric Using Sulfamate and Urea Mixture, AASCIT Journal of Materials, 1 (4): 98-110.

[12] Nunna S., Chandra P.R., Shrivastava S. 2012. A review on mechanical behavior of natural fiber based hybrid composites, Journal of Reinforced Plastics and Composites, 31 (11): 759-769. 